\title{
Suggestopedia Method as an Effective Method in Teaching Reading Comprehension for Senior High School
}

\author{
Deavy Murfita Safitri
}

\author{
Dian Novita \\ English Education Study Program, Faculty of Teacher Training and Education \\ Universitas Muhammadiyah Sidoarjo, Indonesia Jl. Mojopahit, 666B, Sidoarjo
}

*Email: d.murfita@yahoo.co.id

\begin{abstract}
This research is to know is there is significant effect in reading comprehension achievement in $\mathrm{X}$ grade at SMK Walisongo $1 \mathrm{Gempol}$, being taught by suggestopedia method. This research uses quantitative research. The research's object is X AK-2 of SMK Walisongo 1 Gempol has 28 students. The researcher divides the main activity into pre-test, treatment and post-test. Based on the SPSS 23 Program calculation from mean result of pre-test 70.1 and the result mean of post-test is 83.5. The students' score is increasing after being given by the treatment. The result of the calculation of this research showed that (sig 2-tailed = 0.002 ) which is less from $(<) 0.05$ and significance $5 \%$. It mean that the alternative hypothesis is accepted and the null hypothesis is rejected. From the result of the data analysis above, the use suggestopedia method gives significant effect in students' reading comprehension achievement.
\end{abstract}

Keyword: suggestopedia, teaching reading comprehension

\section{INTRODUCTION}

Language is a tool for communicating to each other. We use our own language to make the other people understand with our purpose and we know the purpose. Language is a kind of communication process through symbols and sounds, so we can show our feelings, thoughts, ideas, and experiences [1]. There are many languages in a whole world. Most of the countries use English as first language in their country. On the other hand, Indonesian still use Bahasa as their first language. But this globalization era brings us to see the reality that we must master English for oral and written.

Nowadays, English becomes the most important skill that we must have to face the world. Every aspect of life such as: Economy, Politics, Science, Technology need English skill as a basic language. It means that some aspects of life depend on what skill we have and what language we speak. English have four skills that students must have; they are reading, listening, speaking and writing [2].

Indonesian government always try to make education better and ready to face globalization era through English teaching and learning process in all level of education. So, students must have four skills in English language to face the globalization era. Reading is one of those skill that some students must have. In this skill, we have to be more focus to understand the meaning. Reading is a skill which is fundamental that every students should be mastered as good as speaking, listening, and writing [3] The researcher can give conclusion that the students need something new in teaching and learning reading skill. Based on this study, the researcher chooses one method for teaching junior high school students to know how the method gives effect for students or it will not give any effect. The researcher chooses Suggestopedia method. There is a classical music during the learning process. It will make the students relax and enjoy the learning process. In 1978, a Bulgarian psychotherapist, Lozanov has been researched about Suggestopedia method and he stated that relaxation techniques and concentration will help the students open their subconscious resources and acquire and master the vocabulary more many and also structures more focus than they think.

\section{METHODOLOGY}

This research uses quantitative research to arrange and take all the data. Quantitative research which use scientific method because in quantitative research based on empirical, objective, rational and systematically [4]. In this research, the researcher uses experimental research. Experimental designs are one of procedures in quantitative research [5]. For this research, the researcher used true experimental design to organize the research data and the researcher know the effect of Suggestopedia method for teaching reading comprehension at SMK Walisongo 1

Gempol. True experimental design into two groups. For the first group is experimental group and the purpose to get the treatment. Then, the second is control group but it does not get the treatment. There are two characteristics of true experimental design, such as there is a control group and the sample is drawn randomly. The researcher will give a treatment to the experimental group of using Suggestopedia method.

Firstly, before the researcher give a treatment, the researcher will give a pre-test to the students who will be target of treatment. This things have purpose to know how far the students' understanding about narrative text. The last is post-test. The purpose of post-test is to know narrative text understanding after giving treatment of Suggestopedia method. The research conducted to analyze if there is any significant effect for teaching narrative text at SMK Walisongo 1 Gempol, before and after 
giving the treatment. If the students post-tests' score and narrative text understanding, it means that Suggestopedia is suitable method to increasing students' narrative text understanding than do not use Suggestopedia method.

The researcher uses two variables, they are independent and dependent variable. The researcher who takes the population is all of the tenth grade of SMK Walisongo 1 Gempol. The number of population is 324 students. For the sample, the rsearcher chooses X AK-1 and X AK-2. The researcher choose a test as an instrument. A test is one of methods to assess someone ability or knowledge in a given domain [6]. The researcher arranged 18 questions for the pre-test and post-test. The questions consist of the characters, moral value, vocabulary and the main idea in narrative text. Pre-test is a test which doing in observation before the researcher gives a treatment. Post-test is a test which doing in observation after the researcher gives a treatment.

Data analysis is activity after all the data from all participants or the other sources completely. The researcher uses statistics to analyze the result of experimental design. The result is to make comparison with the average of two samples with the interval. Then, the researcher does examination by using normality test and homogeneity test. Normality test is a test that is used to know whether the data distribution in a group of data or variable is normal or not. Homogeneity test has function to know about the variance between two groups or several groups that have different subject or data source. The reading comprehension test is form of multiple chose test. The score is 1 for the correct answer, and 0 for the wrong answer. The following formula is used to obtain of the total score.

$$
S=-\mathbf{X} 100
$$

n

Note:

$\square \mathrm{S}=$ score

$\mathrm{R}=$ total number of the correct answer

$\mathrm{n}=$ total number of items

The analysis of the data will be conduct after collecting the data. The purpose of this research is to find the effectiveness of using suggestopedia method for teaching reading comprehension at SMK Walisongo 1 Gempol.

\section{FINDING AND DISCUSSION}

The researcher explained the result of the test that had been done by two groups, they are experimental and control class. The researcher gave pre-test before the researcher gave the treatment. Then, the researcher analyzed the result or the score of the students' pre-test. After the researcher gave pre-test to the students, they were given a treatment for experimental class. The experimental class or X AK 2 got Suggestopedia method and for control class or X AK 1 did not get the Suggestopedia method. After the researcher gave the treatment, the researcher gave the post-test to know the differences between before and after given the treatment.In data analysis, it was used t-test to count and find the result. There are three points, seeking normality of test, seeking homogeneity of test, then did the t-test.In this chapter explains the analysis of experimental study result which had been conducted in SMK Walisongo 1 Gempol in academic year of 2017/2018. The researcher began from May $07^{\text {th }} 2018$ until May $25^{\text {th }} 2018$.

The researcher got the result from the pre-test that was conducted on Wednesday, of 9 May 2018. The researcher gave pre-test to experimental class or X-AK 2. After that, the researcher got the highest score of experimental class. The highest score was 88 and the lowest score was 55. The duration of the pre-test was 30 minutes. The researcher also gave pre-test in control class or X-AK 1 . There were 18 questions of multiple choice which took from narrative text (legend). There were 28 students that followed the pre-test. After that, the researcher got the highest score of experimental class. The highest score was 88 and the lowest score was 50. The duration of the pre-test was 30 minutes. Firstly, the researcher gave the first treatment to the experimental class on Wednesday of $09^{\text {th }}$ May 2018. The treatment was given after pre-test was done. The pre-test was taken about 30 minutes. The treatment was taken about 60 minutes. The treatment was done in experimental class (X-AK 2). Firstly, the researcher gave a text to the students about Narrative text (The legend of Banyuwangi). The researcher gave the text individually. Before the treatment was given, the researcher asked to the students to close their eyes. Then, the researcher gave positive suggestion to them. So, the researcher made the atmosphere of the class became relax and quiet enough. The researcher began to play the Beethoven's classical music which titled was Fur Elise. During the song was played, the researcher read the narrative text (The legend of Banyuwangi) slowly followed the song. The researcher repeated that activity twice. After that, the researcher gave some question to the students, and there were some students can answer the question directly.

The second treatment was on Wednesday $16^{\text {th }}$ of May 2018. In the second treatment almost same but different song and narrative text. The researcher gave a text one by one to the students which title was "Timun Mas". Then, the song was still Beethoven's classical music which titled was Silence. After the researcher read the text followed by the music. The researcher asked to the students read the text in front of the class with their own expression. Then, the researcher called the students' name and the students came forward. Then, the students read the text.

After the researcher gave pre-test to the students and gave treatment to experimental class or X-AK 2. Then, the researcher did the last activity. The researcher gave post-test to both of class on Wednesday of $23^{\text {th }}$ May 2018. After that, the researcher got the result from the post-test and the researcher found the highest score. There were two students who got 100 . Then, there was one students got the lowest score was 61 . The duration of the post-test was 30 minutes. The researcher also gave posttest to the control group or X-AK 1 . The post-test was held on Wednesday of $23^{\text {th }}$ May 2018 . There were 28 students who follow 
the post-test. Then, the researcher got the result form the post-test. The researcher found the highest score was 94 and the lowest score was 55. The duration of the post-test was 30 minutes.

Then, based on SPSS 23 Program calculation showed that (significance) value $>0.05,0.965>0.05$. So, Pre-test data is homogeny. Based on SPSS 23 Program calculation showed that (significance) value $>0.05,0.501>0.05$. So, Post-test data is homogeny. From SPSS 23 Program calculation showed that (significance) value $0.066>0.05$, it means that distribution of Experimental class Pre-test data was Normal.

Then, from SPSS 23 Program calculation showed that (significance) value $0.139>0.05$, it means that distribution of Control class Pre-test data was Normal. From SPSS 23 Program calculation showed that (significance) value 0.133

$>0.05$, which means that distribution of Experimental class Post-test data was Normal.

Then, from SPSS 23 Program calculation showed that (significance) value $0.343>0.05$, which means that distribution of Control class Post-test was Normal. Based on SPSS 23 Program calculation showed that (sig 2-tailed=0.002) which less from $(<$ ) 0.05. So, it can be concluded that null hypothesis was rejected and alternative hypothesis was accepted.

The researcher formulates the alternative hypothesis and the null hypothesis, as below: The alternative hypothesis (Ha) : There is a significant effect after using Suggestopedia method on students' reading comprehension at SMK Walisongo 1 Gempol. The null hypothesis (H0) : There is no significant effect after using Suggestopedia method on students' reading comprehension at SMK Walisongo 1 Gempol If the (significance) value or sig (2-tailed) $<0.05$, the null hypothesis was rejected. It means that there is significant difference result in learning reading comprehension after being taught by Suggestopedia method. If the (significance) value or sig (2-tailed) $>0.05$, the null hypothesis was accepted. It means that there is no significant difference result in learning reading comprehension after being taught by Suggestopedia method.

The value of $\mathrm{t}$ table in significance $5 \%=0.05$, The value $=0.002$. The researcher got ( $\mathrm{sig} 2$-tailed=0.002) which less from $(<)$ 0.05. It can be concluded that null hypothesis was rejected and alternative hypothesis was accepted. So, this research there is significant different result in learning reading comprehension before being taught by using Suggestopedia method and after being taught by using Suggestopedia method.

\section{CONCLUSIONS}

Based on the data which the researcher got from the pre-experimental researcher at the tenth grade students of SMK Walisongo 1 Gempol, the researcher got the students' experimental pre-test score $\left(\sum x=1963\right)$, the mean is 70.1 and the students' control pre-test score $\left(\sum x=1907\right)$, the mean is 70.6. Meanwhile, the researcher got the students' experimental post-test score $\left(\sum x=2338\right)$, the mean is 83.5 and the students' control post-test score $\left(\sum x=2026\right)$, the mean is 75.03 . Based on the $t$-test calculation showed that (sig 2-tailed=0.002), which less from $(<) 0.05$. So, it can be concluded that Suggestopedia method can give significant effect to the students' reading comprehension. Based on the data and the result of the finding and observation on the previous chapter. The researcher would like to give some suggestion. The researcher gave suggestion for the teacher to use Suggestopedia method for alternative method of teaching reading comprehension. Then, the teacher can make a relax atmosphere to build the students' interest especially in reading. The students should gave a positive suggestion to themselves especially before the learning process began. Because positive suggestion can stimulate the brain to think positive too. For another researcher, the researcher knew that this research was not perfect. There were many weakness and might be for later researcher can develop and make this research better. The weakness of this research when the method was applied in the class. In the beginning, the students were noisy and difficult to handle. There was a challenge in the beginning to make them relax and focus.

\section{ACKNOWLEDGMENT}

The researcher would like convey her special gratitude for her beloved parents and my beloved husband who have given love, care, motivation, sacrifice and so much opportunities for her to study more. So that, the researcher can finish this thesis. All the teacher, staffs, stakeholder and the students of SMK Walisongo 1 Gempol. All her beloved friends in English Education Department, especially friends from Morning-A1class. Thank you so much for the nice brotherhood and sisterhood during this four years.

\section{REFERENCES}

1. Goldstein, E. Bruce. (2008). Cognitive Psychology: Connecting Mind, Research, and Everyday Experience. pp12-13

2. Harmer, Jeremy. (1991). the Practice of English Language Teaching, New Edition. New York

3. Novita, Dian. (2018). Syndicate Learning: An Alternative Approach For Teaching Extensive Reading. pp 1

4. Sugiyono, Dr, Prof. (2017). "Metode Penelitian Kuantitatif Kualitatif, R\&D"

5. Creswell, John W. (2014). Educational Research. pp 22

6. Brown, H. Douglas, (2004). Language Assessment: Principles and Classroom Practices. San Fransisco US: State University. pp 44 